\title{
WACANA HUMOR DALAM MEME DI MEDIA ONLINE SEBAGAI POTRET KEHIDUPAN SEBAGIAN MASYARAKAT INDONESIA
}

\author{
Ari Listiyorini \\ FBS Universitas Negeri Yogyakarta \\ email: listiyoriniari@gmail.com
}

\begin{abstract}
Abstrak
Penelitian ini bertujuan mendeskripsikan tema dan topik, implikatur, dan aspek kebahasaan yang terdapat dalam wacana humor meme di media online. Penelitian menggunakan desain penelitian deskriptif. Sumber data penelitian adalah 70 buah meme di empat situs meme media online, yaitu www.memecomicindo.com, www.indomeme. com, www.memecomic.id, dan www.1cak.com. Hasil penelitian sebagai berikut. Pertama, terdapat empat buah tema meme dalam media online, yaitu tema sosial, politik, hukum, dan agama. Kedua, ditemukan tiga implikatur dalam meme di media online, yaitu menyindir, menyarankan, dan gabungan antara menyindir dan menyarankan. Ketiga, terdapat dua aspek kebahasaan yang mendukung implikatur dan menimbulkan kelucuan dalam meme, yaitu aspek fonologis dan aspek semantis. Aspek fonologis yang ada yaitu pengulangan bunyi atau dalam sastra sering disebut dengan istilah rima/persajakan. Aspek semantis meliputi pengulangan kata, penggunaan simile, metafora, hiperbola, personifikasi, silogisme, singkatan, dan peribahasa.
\end{abstract}

Kata kunci: tema, topik, implikatur, aspek kebahasaan, meme

\section{HUMOR DISCOURSE IN MEMES IN ONLINE MEDIA AS PORTRAITS OF THE LIFE OF SOME INDONESIAN COMMUNITIES}

\begin{abstract}
This study aims to describe themes and topics, implicatures, and language aspects in humor discourse in memes in online media. The study employed the descriptive research design. The data sources were 70 memes in four sites of online meme media, i.e. www. memecomicindo.com, www.indomeme.com, www.memecomic.id, and www.1cak.com. The results of the study are as follows. First, there are four meme themes in online media; they are social, political, legal, and religious themes. Second, there are three implicatures in memes in online media, namely insinuation, suggestion, and the combination of insinuation and suggestion. Third, there are two language aspects that support implicatures and result in humor in memes, namely the phonological and semantic aspects. The phonological aspect includes the repetition of sounds which in literature is often called a rhyme. The semantic aspect comprises the repetition of words and the use of similes, metaphors, hyperboles, personifications, syllogisms, abbreviations, and proverbs.
\end{abstract}

Keywords: themes, topics, implicatures, language aspects, memes

\section{PENDAHULUAN}

Pada masa sekarang ini, seseorang dapat mencurahkan segala pikiran, perasaan, dan gagasannya dengan lebih le- luasa. Pengungkapan pikiran, gagasan, ataupun hal lainnya dapat dilakukan baik dengan komunikasi lisan maupun tulisan. Namun, komunikasi tulisan, untuk 
saat ini lebih sering dijadikan cara untuk mengungkapkan pikiran dan perasaan seseorang. Hal itu dikarenakan saat ini sudah semakin mudah akses untuk berkomunikasi dengan tulisan melalui media internet atau media daring, baik melalui blog, situs, maupun melalui media sosial tertentu.

Selain sebagai media untuk menyampaikan gagasan tentang suatu topik tertentu, misal topik budaya, sosial, politik, atau gosip selebriti, media daring juga dapat dijadikan sebagai sarana untuk memberi hiburan/ humor. Banyak tulisan dan gambar lucu yang sering dimuat dalam media daring tersebut. Humor yang mereka sampaikan ada kalanya ditujukan semata-mata sebagai hiburan, tetapi ada kalanya juga ditujukan sebagai kritikan lewat maksud yang tersirat dalam humor tersebut. Misalnya kritik untuk pemerintah, tokoh politik, atau pejabat negara.

Sehubungan dengan humor di media daring dengan bermacam tema, topik, maksud dan fungsi tersebut, saat ini ada wacana humor yang sedang marak di media internet. Wacana yang dimaksud adalah meme (dibaca: mim). Saat ini meme sangat banyak ditemui di internet, baik melalui situs meme tertentu, seperti www. memecomicindo.com, www.1cak.com, www.na9a.com, maupun facebook, twitter, forum media daring (misal kaskus), dan blog.

Bila dicermati meme adalah wacana berbentuk gambar/ foto dengan tulisantulisan tertentu. Pernyataan ini didukung oleh pendapat Nugraha, dkk. (2015:239) yang menyatakan meme adalah gambar atau foto yang diberi teks atau bahasa sehingga menghasilkan makna baru. Tidak banyak teori yang menjelaskan tentang meme. Istilah meme ini berasal dari bahasa Yunani "mimema" yang berarti sesuatu yang ditiru. Istilah meme sebenarnya sudah cukup lama diperkenalkan oleh ahli biologi Richard Dawkins dalam bukunya
The Selfish Gene tahun 1976 (Shifman, 2013:363). Oleh Dawkins istilah meme digunakan untuk menjelaskan penyebaran ide atau fenomena budaya. Yang termasuk dalam budaya di sini menurut Dawkins, yaitu gagasan, ide, teori, penerapan, kebiasaan, lagu, tarian, dan suasana hati. Meme dapat bereplikasi dengan sendirinya (dalam bentuk peniruan) dan membentuk suatu budaya. Cara seperti ini dikatakan mirip dengan penyebaran virus, tetapi dalam hal ini terjadi di ranah budaya. Penyebaran meme ini dikemukakan juga oleh Bauckhage (2011:42) yang menyatakan bahwa meme biasanya berkembang melalui komentar, imitasi, atau parodi, atau bahkan melalui berita di media lain. Berkaitan dengan meme juga, Pusanti dan Haryanto (2017) menyimpulkan meme sebagai suatu informasi yang dapat berupa ide, ideologi, gambar, musik, video,susunan kata, serta hashtag yang menjadi populer karena tersebar begitu cepat dan mampu mendiami benak masyarakat selayaknya virus. Meme dapat tersebar secara cepat dari satu orang ke orang lain melalui media daring/ melalui koneksi internet. Media daring dalam hal ini dapat dimaknai sebagai sarana komunikasi secara daring. Oleh karena itu, email, mailing list, website, blog, whatsapp, dan media sosial masuk dalam kategori media daring.

Gambar dan tulisan yang ada dalam meme tersebut bersifat lucu/ menghibur dan sering membuat orang tersenyum bila membaca meme tersebut. Akan tetapi, walaupun kelihatan lucu, ternyata dalam meme tersebut terdapat maksud/ implikatur tertentu yang hendak disampaikan pembuatnya. Fungsi dan maksud tersebut tidak hanya sekedar menghibur, tetapi juga maksud yang lain seperti menyindir, mengejek, mengkritik, dan sebagainya.

Berikut ini contoh meme yang ada di media daring. 


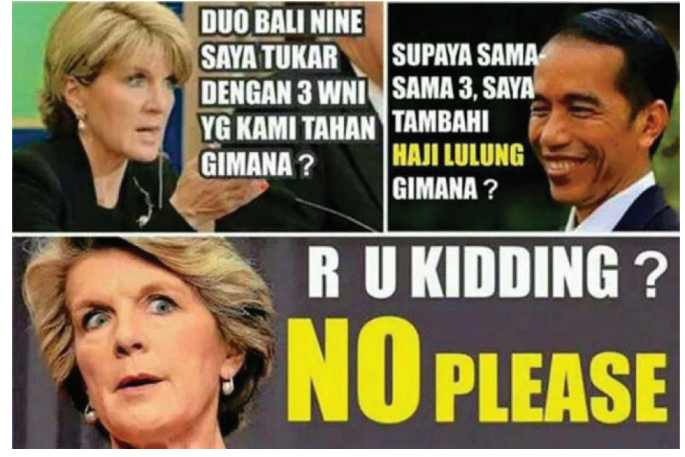

Sumber: http://internasional.metrotvnews.com

Pada contoh meme di atas terdapat percakapan antara Presiden Jokowi dengan Menteri Luar Negeri Australia yang membahas topik tentang pertukaran tahanan narkoba kasus Duo Bali Nine yang diminta oleh pihak Australia. Permintaan tersebut ditanggapi oleh Presiden Jokowi dengan menukarnya dengan Haji Lulung. Konteks pada saat meme ini dibuat, Haji Lulung, merupakan salah satu anggota DPRD Jakarta yang terkenal dengan perseteruannya dengan Gubernur Jakarta, Ahok. Pembuat meme ini mempunyai maksud tertentu lewat tulisan dan gambar yang dibuatnya.

Jika dilihat dari contoh meme yang telah dipaparkan di atas, dapat dikatakan meme merupakan suatu bentuk wacana. Salah satu pengertian wacana menurut Kamus Besar Bahasa Indonesial KBBI (2005:1265) adalah keseluruhan tutur yang merupakan suatu kesatuan. Wacana sebagai satuan bahasa yang paling besar yang digunakan dalam komunikasi (Rani, dkk. (2004:3). Dalam wacana ada tiga hal yang sentral, yaitu teks, konteks, dan wacana (Cook, via Eriyanto, 2006:9). Dalam meme terdapat keseluruhan tutur yang merupakan satu kesatuan. Selain itu, ada teks dan konteks dalam meme tersebut. Ada teks dalam meme, yaitu bentuk bahasa, bukan hanya kata-kata yang tercetak di lembar kertas, tetapi juga semua jenis ekspresi komunikasi. Ada juga konteks dalam meme, yaitu semua situasi dan hal yang berada di luar teks dan mempengaruhi pemakaian bahasa, seperti partisipan dalam bahasa, situasi tempat teks tersebut di produksi, fungsi yang dimasukkan, dan sebagainya. Selanjutnya, wacana dimaknai sebagai teks dan konteks bersama-sama yang muncul dalam meme.

Secara kasat mata meme adalah wacana berbentuk gambar dengan tulisantulisan tertentu yang bersifat menghibur (humor). Humor merupakan aktivitas kehidupan yang sering dilakukan oleh masyarakat dan menjadi bagian hidup masyarakat. Dengan humor seseorang dapat mengungkapkan ide/ gagasan dan pikiran, baik dengan kata-kata (verbal) atau dengan jalan lain yang melukiskan suatu ajakan yang menimbulkan simpati dan hiburan. Humor dalam meme dapat menjadikan seseorang bisa tertawa. Namun, humor tersebut bisa juga menjadikan seseorang berpikir dan mawas diri karena adakalanya bahkan sering humor sebenarnya berisi kritikan pada seseorang ataupun suatu hal.

Humor yang beredar di masyarakat memiliki beragam bentuk dan fungsi. Dari bentuknya humor dalam meme merupakan campuran antara gambar dan tulisan. Pada humor meme yang berisi campuran antara gambar dan tulisan dapat dilihat aspek kebahasaan (verbal) yang meliputi kata, frase, klausa, dan kalimat. Dari segi fungsi, humor dapat digunakan sebagai sarana protes sosial, sebagai sarana pendidikan, sarana hiburan, dan sebagai media memperbaiki akhlak atau moral (Danandjaja, 1986). Begitu juga halnya fungsi humor dalam meme.

Gambar dan tulisan yang ada dalam meme bersifat lucu/ menghibur dan membuat orang selalu tersenyum bila membaca meme tersebut. Akan tetapi, walaupun kelihatan lucu, ternyata dalam meme tersebut terdapat maksud/ implikatur tertentu yang hendak disampaikan pembuatnya.

Secara etimologis implikatur diturunkan dari kata implicatum. Secara nomi- 
nal, istilah ini hampir sama dengan istilah implication, yang artinya maksud, pengertian, keterlibatan (Echols, dkk., 1984:313). Implikatur percakapan menurut Levinson (via Mulyana, 2005:13) merupakan pemahaman terhadap hal "yang dimaksudkan" yang sangat tergantung kepada konteks terjadinya percakapan. Implikatur ini bersifat temporer karena hanya terjadi saat berlangsungnya suatu percakapan. Selain itu, bersifat nonkonvensional yang berarti sesuatu yang diimplikasikan tidak mempunyai relasi langsung dengan tuturan yang diucapkan. Jadi, implikatur yang terdapat dalam meme dapat dipahami dengan melihat konteks kehidupan masyarakat saat meme dibuat.

Dari uraian yang telah dipaparkan di atas, yang menjadi tujuan penelitian ini, yaitu mendeskripsikan (1) tema dan topiktopik kehidupan masyarakat yang ada dalam meme di media daring tersebut, (2) implikatur yang terdapat dalam wacana humor meme di media daring, dan (3) aspek-aspek kebahasaan yang mendukung implikatur dan dapat menimbulkan kelucuan dalam meme di media daring.

\section{METODE}

Penelitian ini menggunakan desain penelitian deskriptif yang bertujuan memberikan atau menjabarkan suatu keadaan atau fenomena yang terjadi pada saat ini. Sumber data dalam penelitian ini adalah 70 buah meme di 4 situs meme di media daring, yaitu www.memecomicindo. com, www.indomeme.com, www.memecomic.id, dan www.1cak.com. Meme yang diambil yaitu meme yang dimuat pada bulan April-September 2015. Dipilih 70 meme yang tidak berwujud komik atau rangkaian dari berbagai gambar. Instrumen penelitian yang digunakan, yaitu human instrument, perangkat keras berupa komputer, laptop, printer, alat tulis, dan perangkat lunak berupa indikator/ kriteria tema dan topik dan implikatur serta aspek kebahasaan yang terdapat dalam meme di media daring berdasarkan teori yang dijadikan acuan dalam penelitian ini. Untuk pengumpulan data digunakan metode capture dan cetak, metode simak/ baca secara cermat, dan catat. Metode padan dan agih digunakan untuk menganalisis data dalam penelitian ini. Validitas yang digunakan dalam penelitian ini, yaitu validitas isi dan validitas semantik. Reliabilitas dalam penelitian ini, yaitu reliabilitas intrareter dan intereter.

\section{PEMBAHASAN}

Pada bagianini akan diuraikan hasil penelitian yang telah dilakukan beserta pembahasaannya. Hal yang akan diuraikan meliputi tema dan topik meme dalam media daring, implikatur yang terdapat dalam meme di media daring, dan aspek-aspek kebahasaan yang mendukung implikatur dan dapat menimbulkan kelucuan dalam meme di media daring.

Tabel 1. Tema dan Topik dalam Situs Meme di Media Daring

\begin{tabular}{|c|c|c|c|c|}
\hline No. & Tema & Topik & Jumlah & Total \\
\hline \multirow[t]{5}{*}{1.} & & a. Cinta & 20 & 57 \\
\hline & \multirow{4}{*}{ Sosial } & b. Sekolah & 8 & \\
\hline & & c. Persahabatan & 3 & \\
\hline & & d. Hubungan dengan orang lain & 6 & \\
\hline & & e. Kehidupan sosial lainnya & 20 & \\
\hline 2. & Politik & DPR, Anggota DPR, hater presiden & 4 & 4 \\
\hline 3. & Hukum & Polisi dan aturan berlalu lintas & 2 & 2 \\
\hline 4. & Agama & $\begin{array}{l}\text { Puasa, sholat, qurban, lebaran/idhul fitri, } \\
\text { ibadah kerja }\end{array}$ & 7 & 7 \\
\hline & & TOTAL & & 70 \\
\hline
\end{tabular}




\section{Tema dan Topik yang Terdapat dalam Meme di Media Daring}

Dari 70 meme yang diambil dari empat situs meme yang telah diteliti dapat digolongkan tema dan topik meme di media daring dapat dilihat pada tabel 1.

Dari tabel 1 dapat diketahui bahwa terdapat 4 tema dalam meme di media daring yang diteliti, yaitu tema sosial, politik, hukum, dan agama. Tema sosial berhubungan dengan masyarakat. Tema politik berhubungan dengan ketatanegaraan atau kenegaraan (seperti tentang sistem pemerintahan, dasar pemerintahan) dan segala urusan dan tindakan (kebijakan, siasat, dan sebagainya) mengenai pemerintahan negara atau terhadap negara lain. Sementara itu, tema hukum berkaitan dengan peraturan atau adat yang secara resmi dianggap mengikat, yang dikukuhkan oleh penguasa atau pemerintah, undangundang, peraturan, dan sebagainya untuk mengatur pergaulan hidup masyarakat, dan patokan (kaidah, ketentuan) mengenai peristiwa (alam dan sebagainya) yang tertentu. Selanjutnya, hal yang berkaitan dengan ajaran, sistem yang mengatur tata keimanan (kepercayaan) dan peribadatan kepada Tuhan Yang Mahakuasa serta tata kaidah yang berhubungan dengan pergaulan manusia dan manusia serta lingkungannya dimasukkan dalam tema agama (lihat KBBI, 2005).

Jika dilihat dari tabel 1, dapat dilihat cukup banyak tema dan topik meme yang ada di media daring. Dari 4 tema yang ada dalam wacana meme, tema sosial paling banyak ditemukan. Topik-topik dalam tema sosial ini meliputi cinta, sekolah, persahabatan, hubungan dengan orang lain, dan kehidupan sosial lainnya. Topik yang paling banyak muncul, yaitu tentang cinta (walaupun secara frekuensi sama dengan topik kehidupan sosial lainnya, tetapi topik di kehidupan sosial lainnya terdiri dari sub-subtopik lagi). Hal ini dikarenakan baik pengelola situs meme maupun netizen pembuat dan pengirim meme sebagian besar memang anak muda. Selanjutnya, hater presiden, DPR, anggota DPR, merupakan topik dari tema politik. Topik dari tema hukum berkaitan dengan polisi dan aturan berlalu lintas dan yang terakhir topik puasa, sholat, qurban, idhul fitri, dan ibadah kerja termasuk dalam tema agama. Berikut ini beberapa contoh meme dengan tema sosial dengan topik cinta, sekolah, dan persahabatan.

\section{Meme dengan Topik Percintaan}

Banyak sekali meme dengan topik percintaan atau hubungan antara lakilaki dan perempuan. Hal ini dikarenakan sebagian besar pengelola situs meme dan netizen pembuat meme adalah anak muda, walaupun ada juga pembuat meme yang berusia dewasa. Berikut ini contoh meme dengan topik percintaan.

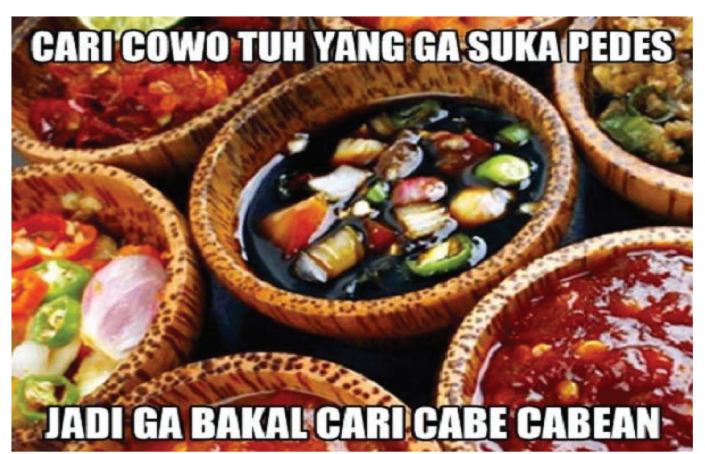

www.memecomicindo.com

Dalam meme di atas disebutkan "Cari cowok tuh yang ga suka pedes. Jadi ga bakal cari cabe-cabean". Pembuat meme menyarankan bahwa seorang cewek (perempuan) kalau mencari cowok/ pacar tidak usah yang suka pedas karena nanti cowok tersebut tidak akan mencari cabecabean atau gadis di bawah umur yang mulai merintis bisnis prostitusi. Cabecabean digambarkan dengan beraneka cabe yang dibuat sambal dengan tempat dari kayu/ bambu.

\section{Meme dengan Topik Sekolah}

Berikut ini meme dengan topik sekolah.

LITERA, Volume 16, Nomor 1, April 2017 


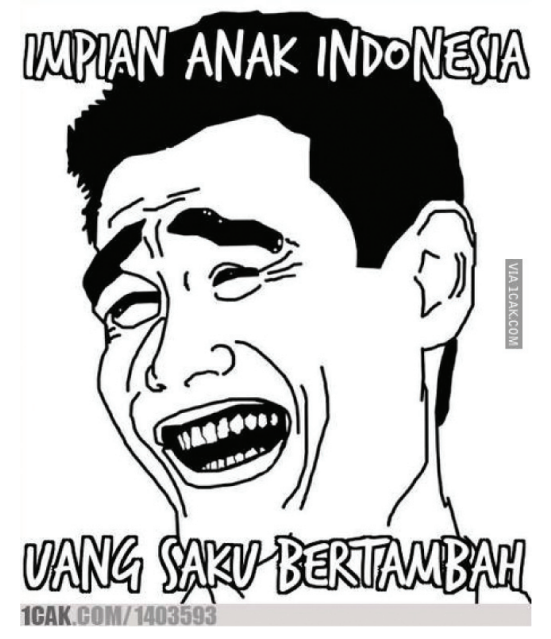

www.1cak.com

Dalam meme di atas berisi wacana "Impian Anak Indonesia: Uang Saku Bertambah". Seperti telah diketahui, anak-anak Indonesia, pada umumnya mendapat uang saku dari orang tuanya ketika hendak berangkat sekolah. Uang saku tersebut biasanya hanya cukup untuk membeli minuman, misal es teh atau minuman lainnya dan sedikit makanan ringan ketika istirahat sekolah. Lewat meme ini, pembuat meme merasa bahwa uang saku yang diberikan orang tuanya kurang atau pas-pasan. Oleh karena itu, pembuat meme berharap uang sakunya ditambah. Untuk menunjukkan bahwa keinginan itu bukan hanya keinginan pribadi pembuat meme, maka ditambahkan "Impian anak Indonesia" untuk menunjukkan keinginan teman-temannya yang merasa kurang pula dengan uang sakunya.

Telah disebutkan sebelumnya bahwa tema sosial mendominasi tema meme di media online. Namun, ada juga meme dengan tema politik, hukum, dan agama yang dapat diuraikan berikut ini. Pada tema politik topik yang dibahas meliputi hater presiden, dan tingkah laku DPR maupun DPRD.

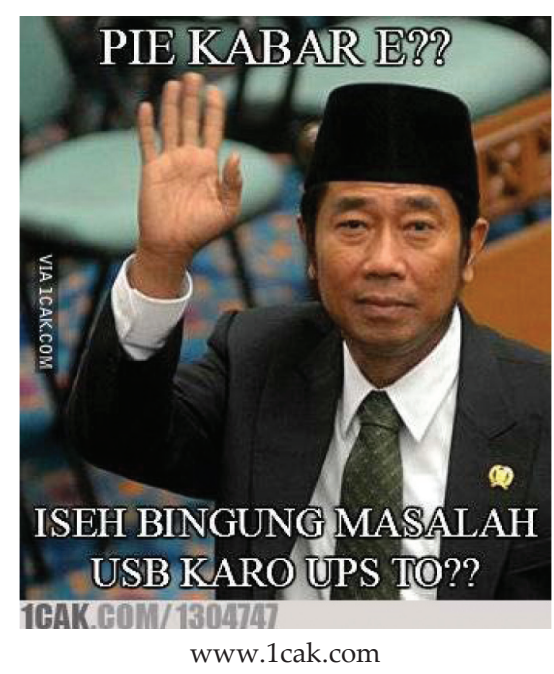

Pada meme di atas berhubungan dengan tingkah laku anggota DPRD DKI Jakarta periode tahun 2014-2019 (Haji Lulung) yang terlibat perseteruan dengan Ahok (Gubernur Jakarta) yang salah menyebut UPS dengan USB. Pembuat meme bermaksud menyindir Haji Lulung yang notabene anggota DPRD tidak bisa membedakan antara USB (universal serial bus) yaitu perangkat penghubung khususnya dalam komputer dengan UPS (uninterruptible power supply) yaitu alat tambahan pada komputer yang berfungsi sebagai cadangan energi listrik. Selanjutnya, meme dengan tema hukum lebih banyak menyoroti antara pengguna jalan raya yang diatur oleh polisi lalu lintas ataupun perilaku pengatur lalu lintas itu (polisi).

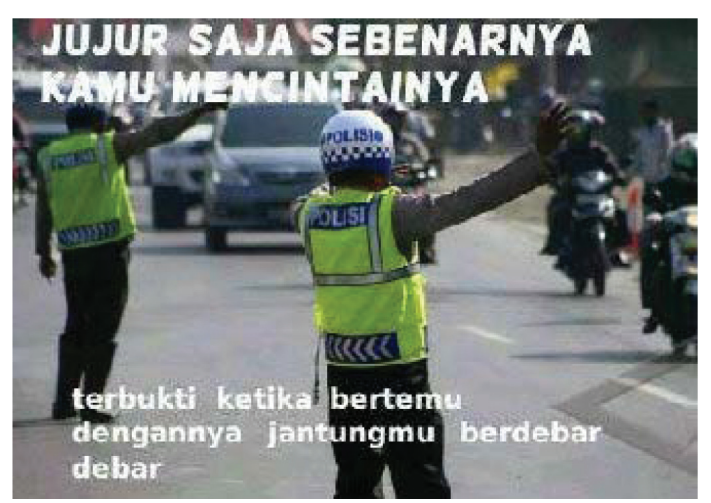

www.memecomicindo.com 
Meme di atas berhubungan dengan hukum yang mempunyai konteks seseorang yang mengendarai kendaraan di jalan raya dia akan berdebar-debar bila melihat polisi di jalan karena mungkin tidak mempunyai atau membawa SIM atau STNK. Pembuat meme mengibaratkan polisi sebagai pacar yang dicintai, yang ketika hendak bertemu hati pasti berdebar-debar. Oleh karena diibaratkan polisi sebagai pacar maka pembuat meme menuliskan kata "mencintainya" padahal pengguna jalan yang tidak menaati peraturan lalu lintas akan takut bila melihat polisi. Yang terakhir meme dengan tema agama berhubungan dengan topik sholat, puasa, qurban, idhul fitri, dan ibadah kerja lainnya. Contoh meme dengan tema agama yaitu sebagai berikut.

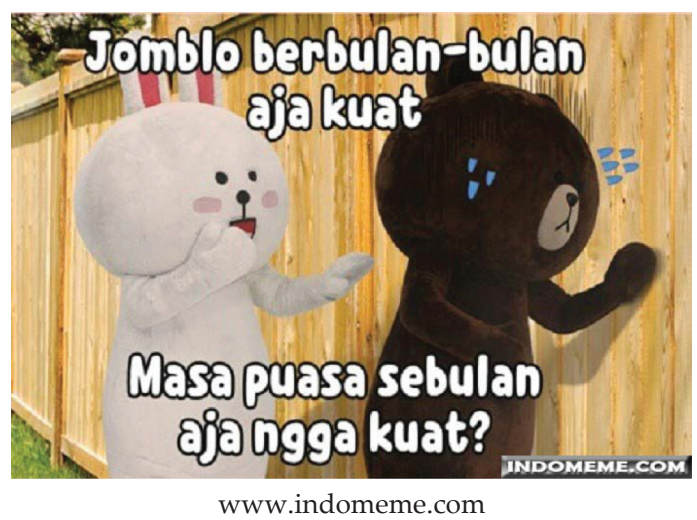

Meme di atas bertema agama dengan topik puasa. Meme ini menyindir seseorang khususnya anak muda yang tidak kuat puasa selama sebulan penuh padahal anak muda tersebut kuat menjomblo (tidak punya pacar) selama berbulan-bulan. Pembuat meme mengajak anak muda supaya kuat menjalani puasa penuh.

\section{Implikatur yang Terdapat dalam Meme di Media Daring}

Secara umum meme dibuat untuk menghibur sekaligus mengungkapkan maksud apa yang pembuat meme rasakan. Seseorang akan membuat meme jika dirasa ada hal-hal yang menggelitik hatinya dan menarik perhatiannya. Hal ini sejalan dengan yang dikemukakan oleh Pusanti dan Haryanto (2017) yang menyebutkan bahwa meme dibuat sebagai penghiburan diri ataupun untuk orang lain dan juga sekaligus menyampaikan isi hati pembuat meme, pesan, kepada seseorang yang mereka tuju. Pesan yang pembuat meme inginkan pada umumnya tidak mereka sampaikan secara langsung, tetapi tersirat lewat wacana meme yang dibuat. Oleh karena itu, banyak terdapat implikatur dalam meme di beberapa situs internet ini. Implikatur ini adalah apa yang mungkin diartikan, disarankan, atau dimaksudkan oleh penutur (dalam hal ini pembuat meme), yang berbeda dengan apa yang sebenarnya disampaikan oleh penutur (Grice, via Brown dan Yule, 1996:31). Untuk mengetahui implikatur yang terdapat dalam meme di media daring ini perlu diperhitungkan informasi-informasi atau konteks yang diketahui terkait dengan peristiwa komunikasi karena implikatur percakapan tergantung pada konteks tertentu (Grice via Yule, 2006:74).

Berikut ini implikatur atau maksud tersirat yang terdapat dalam meme di media daring.

Tabel 2. Implikatur yang Terdapat dalam Meme di Media Daring

\begin{tabular}{llc}
\hline No. & \multicolumn{1}{c}{ Implikatur } & Kemunculan \\
\hline 1. & Menyindir & 32 \\
2. & Menyarankan & 26 \\
3. & Menyindir + & 12 \\
& menyarankan & \\
\hline TOTAL & $\mathbf{7 0}$ \\
\hline
\end{tabular}

Dari tabel 2 dapat diketahui implikatur yang terdapat dalam meme di media daring. Implikatur tersebut yaitu menyindir, menyarankan, dan gabungan antara menyindir dan menyarankan. Implikatur yang paling banyak yaitu menyindir, disusul menyarankan, dan hanya sebagian kecil menyindir sekaligus menyarankan. 
Berikut ini contoh meme dengan implikatur menyarankan.

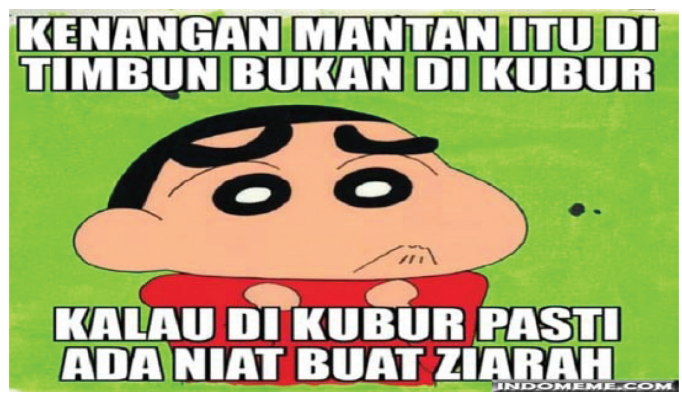

www.indomeme.com

Dalam meme di atas terdapat meme dengan wacana "Kenangan mantan itu di timbun bukan di kubur, kalau di kubur pasti ada niat buat ziarah" dengan gambar meme tokoh kartun shincan dengan ekspresi manyun. Secara tersirat meme tersebut mempunyai implikatur menyarankan kepada pembaca meme bahwa seharusnya mantan (mantan pacar/ mantan suami/ istri) dilupakan dengan menutup segala hal yang berhubungan dengan mantan. Kenangan akan mantan itu ditimbun yang berarti tidak pernah dibuka-buka lagi. Kenangan tersebut bukannya dikubur karena kalau dikubur pasti ada niatan untuk "ziarah" atau membuka-buka lagi ingatan akan mantan tersebut. Implikatur meme ini tidak terlepas dari konteks budaya masyarakat Jawa berkenaan dengan ziarah kubur dimana masyarakat masih menganggap seseorang yang telah meninggal masih memiliki hubungan atau keterikatan dengan orang yang masih hidup sehingga ada waktu-waktu tertentu mereka mengunjungi/ ziarah ke makam untuk mengunjungi dan mendoakan orang yang telah meninggal. Pembuat meme menyatakan bahwa bukan dikubur karena kalau dikubur ada niatan untuk mengunjungi atau mengingat lagi memori-memori akan mantan. Pembuat meme menuliskan ini dikarenakan dalam kehidupan nyata, banyak orang baik anak muda, dewasa, maupun orang tua yang masih selalu mengingat mantannya (mantan pacar atau mantan suami/ istri). Pembuat meme berharap seseorang segera bangkit dan menata diri kembali dengan tidak lagi mengingat masa lalu. Dipilih tokoh shincan untuk menghibur karena shincan terkenal dengan kelucuan dan kegemesannya.

Meme lain dengan implikatur menyindir terdapat pada meme berikut ini.

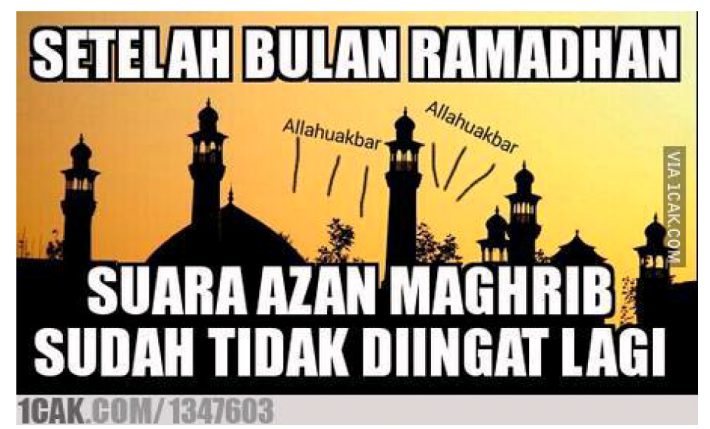

www.1cak.com

Pada meme di atas terdapat wacana "Setelah bulan ramadhan suara azan maghrib sudah tidak diingat lagi" dengan gambar masjid yang mengumandangkan suara adzan. Wacana/ tulisan tersebut tidak hanya sekedar memberitahukan bahwa setelah Bulan Ramadhan suara adzan magrib sudah tidak diingat lagi oleh masyarakat Indonesia. Namun, mempunyai maksud khusus yaitu menyindir masyarakat bahwa ketika setelah Bulan Ramadhan dan mereka sudah tidak puasa lagi, adzan magrib merupakan hal yang biasa dan mereka tidak bergegas lagi untuk shalat magrib seperti halnya ketika bulan ramadhan. Pembuat meme menuliskan wacana ini dari pengamatan terhadap fenome yang ada di masyarakat Indonesia, setiap bulan Ramadhan, banyak orang setia menunggu adzan magrib, bahkan ada istilah yang terkenal dengan istilah ngabuburit. Mereka menunggu adzan magrib karena mereka segera bisa berbuka puasa. Akan tetapi, jika bukan di Bulan Ramadhan banyak orang tetap sibuk beraktivitas masing-masing meskipun sudah terdengar adzan magrib. 
Meme dengan implikatur menyindir ini banyak terdapat pada tema politik. Hal ini dikarenakan meme berkembang menjadi gaya komunikasi baru yang mampu mengandung muatan politik atau sarana guna mengkritisi kebijakan elit negara (Allifiansyah, 2016:152).

Dalam meme ternyata juga terdapat meme dengan beberapa implikatur seperti gabungan antara implikatur menyindir dan menyarankan berikut ini.

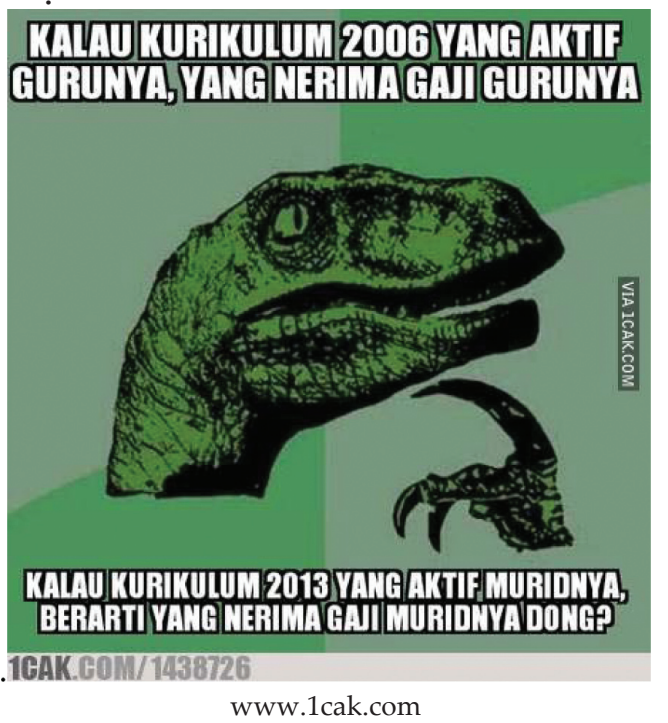

Pada meme di atas terdapat wacana/ tulisan "Kalau kurikulum 2006 yang aktif gurunya, yang nerima gaji gurunya. Kalau kurikulum 2013 yang aktif muridnya, yang nerima gaji muridnya dong?" dengan gambar kepala dinosaurus dengan tangan di bawah dagu seolah manusia yang sedang berpikir. Meme di atas sebenarnya tidak hanya sekedar memberi informasi tentang kurikulum, gaji, dan keaktifan, tetapi sebenarnya mempunyai maksud menyindir dan sekaligus menyarankan pada guru-guru berkaitan dengan kedua kurikulum tersebut. Pada kurikulum 2013 memang ditekankan supaya siswa lebih aktif. Namun, pada kenyataannya guru akhirnya justru cenderung menjadi pasif dan menyerahkan seluruh kegiatan pada siswanya. Pembuat meme menyindir hal ini dan menyarankan supaya guru tetap aktif dan kreatif di kurikulum 2013 ini.

\section{Aspek-Aspek Kebahasaan yang Mendu- kung Implikatur dan Menimbulkan Ke- lucuan dalam Meme di Media Daring}

Meme yang dibuat baik oleh pengelola situs meme maupun kiriman dari netizen memang tidak semuanya lucu karena memang ada yang garing dan jayus (tidak lucu). Namun, dari data yang diambil dalam penelitian ini hampir sebagian besar bersifat lucu dan menghibur, sekaligus juga mempunyai maksud/ implikatur tertentu. Kelucuan ini diwujudkan dari kesatuan antara gambar meme dan aspekaspek kebahasaan yang digunakan untuk mendukung konteks tertentu. Berikut ini uraian aspek-aspek kebahasaan yang

Tabel 3. Aspek-Aspek Kebahasaan yang Mendukung Implikatur dan Menimbulkan Kelucuan dalam Meme di Media Daring

\begin{tabular}{cccc}
\hline No. & \multicolumn{2}{c}{ Aspek Kebahasaan } & Jumlah \\
\hline 1. & Aspek Fonologis & Pengulangan bunyi & 13 \\
2. & Aspek Semantis & Pengulangan kata & 35 \\
& Simile & 6 \\
& Metafora & 4 \\
& Hiperbola & 3 \\
& Personifikasi & 1 \\
& Silogisme & 4 \\
& Singkatan & 1 \\
& & Peribahasa & 3 \\
\hline & & $\mathbf{7 0}$ \\
\hline
\end{tabular}


mendukung implikatur dan mendukung kelucuan dalam meme.

Dari tabel 3 dapat dijelaskan bahwa terdapat dua aspek kebahasaan yang mendukung implikatur dan menimbulkan kelucuan meme, yaitu aspek fonologis dan aspek semantis. Aspek fonologis yang ada yaitu pengulangan bunyi atau dalam sastra sering disebut dengan istilah rima/ persajakan. Sementara itu, aspek semantis meliputi pengulangan kata, penggunaan simile, metafora, hiperbola, personifikasi, silogisme, singkatan, dan peribahasa. Berikut ini uraian penggunaan aspek dan subaspek dalam meme untuk mendukung implikatur dan menimbulkan kelucuannya.

Aspek yang pertama yaitu aspek fonologis yang berupa pengulangan bunyi/ penggunaan rima/ persajakan banyak digunakan dalam wacana meme, yaitu sebanyak 13 kali. Walaupun tidak bisa disebut sebagai puisi, namun ternyata pembuat meme banyak menggunakan hal ini agar meme lebih indah untuk dibaca dan didengarkan. Kekuatan bunyi sebagaimana halnya dengan puisi (lihat Sayuti, 2002:103) dipilih dengan pertimbangan meme diharapkan mampu memberikan atau membangkitkan tanggapan pada pikiran dan perasaan pembaca atau pendengarnya, dapat membantu memperjelas ekspresi, ikut membangun suasana/ konteks, dan mungkin juga mampu membangkitkan asosiasi-asosiasi tertentu. Berikut ini contoh meme dengan pengulangan bunyi di dalamnya.

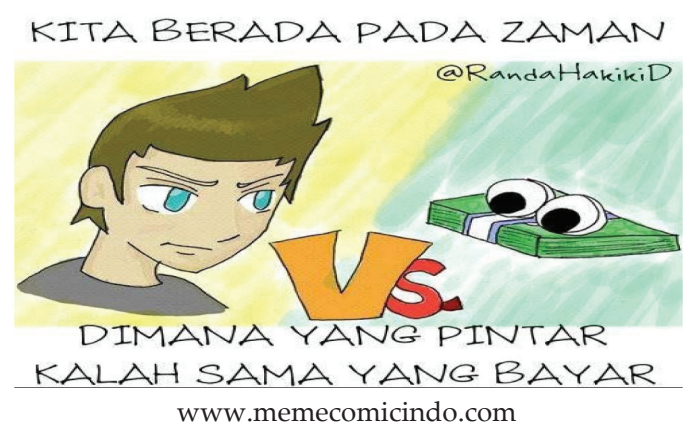

Pada meme di atas terdapat wacana "Kita berada pada zaman dimana yang pintar kalah sama yang bayar" dengan gambar kartun seorang laki-laki vs segepok uang. Pengulangan bunyi yang terjadi yaitu pengulangan bunyi "a" pada kata kita, berada, pada, zaman, dimana, yang pintar, kalah, sama, yang, dan bayar.

Selanjutnya, yaitu aspek yang kedua, yaitu aspek semantis. Aspek semantis berupa pengulangan kata paling banyak digunakan dalam wacana meme, yaitu sebanyak 35 kali. Pengulangan kata-kata dalam meme ini dimaksudkan untuk menonjolkan maksud yang hendak disampaikan. Berikut ini meme dengan pengulangan kata yang terdapat di dalamnya.

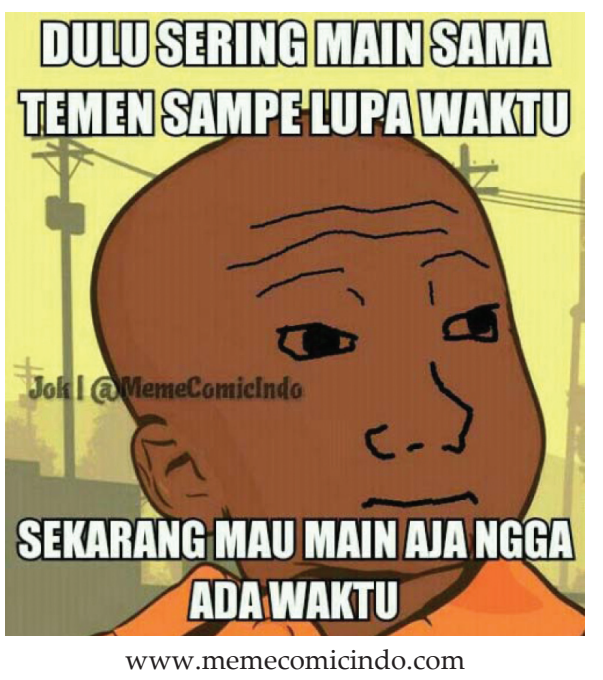

Dalam meme di atas terdapat wacana "Dulu sering main sama temen sampai lupa waktu. Sekarang mau main aja nggak ada waktu" dengan gambar kartun seorang anak laki-laki. Digunakan pengulangan kata waktu untuk menekankan bahwa memang waktu menjadi sesuatu yang sangat penting baik di masa lampau maupun masa kini.

Aspek semantis yang lain yaitu digunakannya simile. Simile atau juga bisa disebut perumpamaan merupakan kiasan yang menyamakan satu hal dengan hal lain menggunakan kata-kata pembanding seperti bagai, laksana, semisal, seumpama, 
sepantun, atau kata-kata lainnya. Berikut ini contoh meme dengan simile.

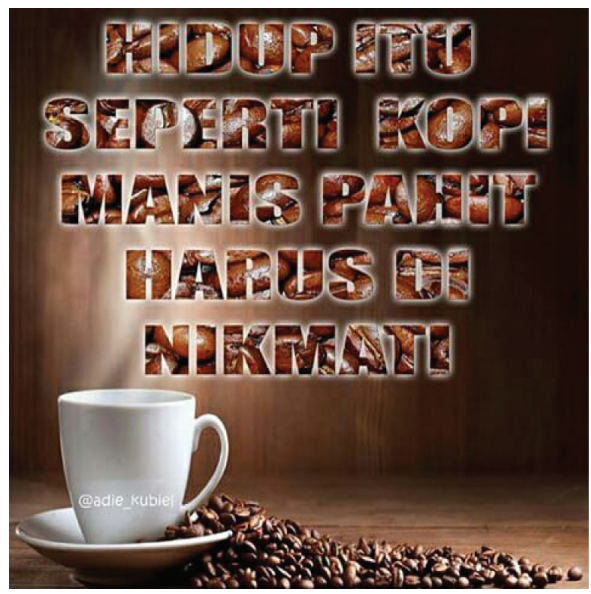

www.memecomicindo.com

Pada meme di atas terdapat wacana "Hidup itu seperti kopi manis pahit harus dinikmati" dengan gambar cangkir dan alas dan banyak kopi di sekitarnya. Dalam wacana tersebut mengumpamakan hidup seperti minum kopi, manis pahit harus dinikmati. Wacana di atas menggunakan kata pembanding seperti.

Selanjutnya, dalam aspek semantis digunakan juga metafora. Metafora ialah membandingkan antara sesuatu hal dengan hal lain yang bersifat tidak langsung dan implisit (Nurgiyantoro, 2012:299). Berikut ini contoh meme yang di dalamnya terdapat metafora.

\section{BUNGKUS CHIKI ZONE}

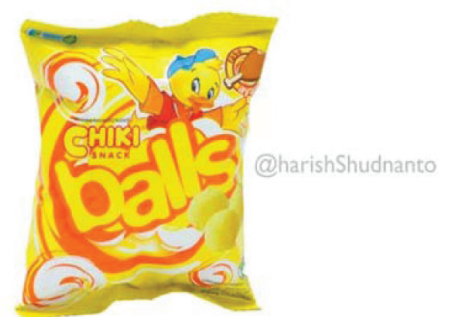

KEADAAN DIMANA ELU AKAN DIBUANG SAMA DOI KETIKA ELU UDAH DIANGGAP SAMPAH

www.memecomicindo.com
Pada meme di atas seseorang yang telah diputus cintanya oleh pacarnya diibaratkan dengan bungkus makanan ringan chiki yang ketika sudah habis dan tinggal sampah pembungkusnya saja akan dibuang (diputus dan ditinggalkan).

Hiperbola juga digunakan untuk mendukung implikatur dan mendukung kelucuan dalam meme di media online. Hiperbola adalah suatu cara penuturan yang bertujuan menekankan maksud dengan sengaja melebih-lebihkannya (Nurgiyantoro, 2012: 300). Berikut ini contoh meme dengan hiperbola di dalamnya.
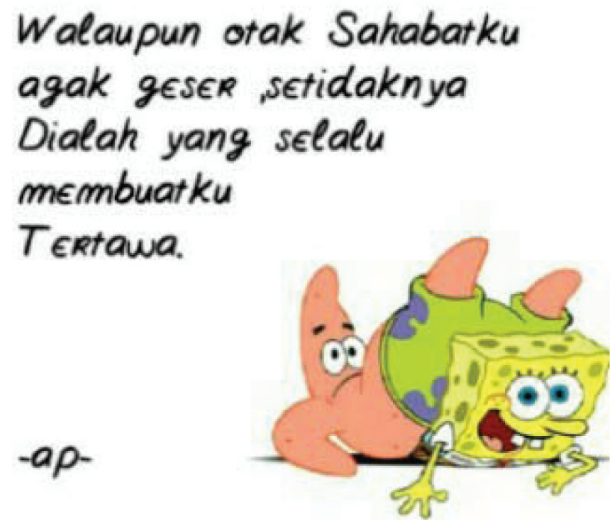

www.memecomicindo.com

Pada meme di atas terdapat wacana "agak geser otaknya" yang merupakan hiperbola dari kata kurang tanggap, yang dalam meme tersebut diumpamakan dengan tokoh kartun Patrick dalam film Spongebob.

Personifikasi yang merupakan gaya bahasa yang memberi sifat-sifat benda mati dengan sifat-sifat seperti yang dimiliki manusia sehingga dapat bersikap dan bertingkah laku sebagaimana halnya manusia (Nurgiyantoro, 2012: 299) juga digunakan dalam wacana humor pada meme. Personifikasi pada contoh meme berikut ini memberi sifat pada kasur yang seolah-olah bisa berbisik untuk tetap di tempat tidur ketika seseorang hendak bangun lari pagi. 


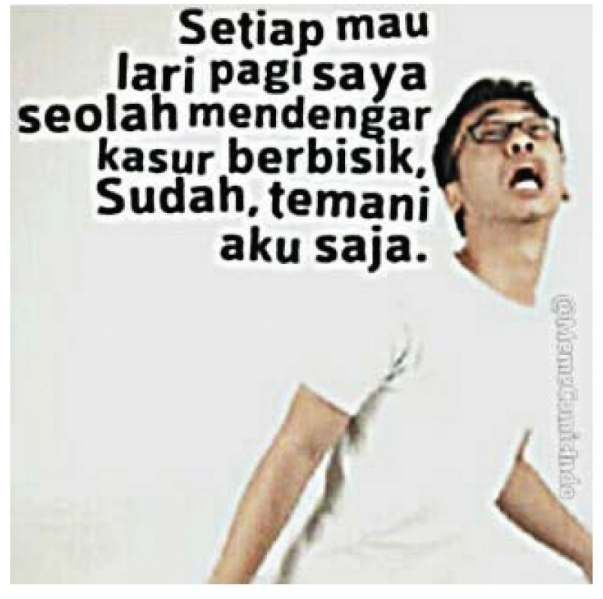

www.memecomicindo.com

Aspek semantis berikutnya yaitu penggunaan silogisme, yaitu bentuk, cara berpikir atau menarik simpulan yang terdiri atas premis umum, premis khusus, dan simpulan (KBBI, 2005 :1066). Contoh berikut ini menggunakan silogisme.

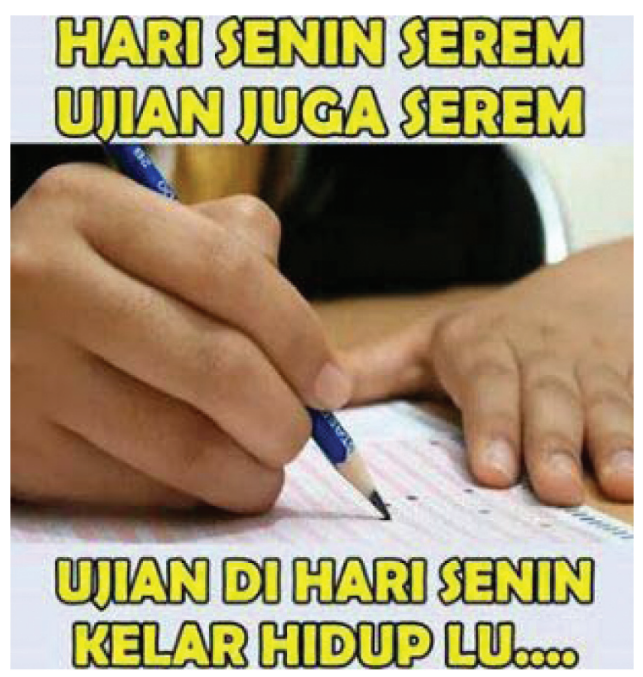

www.memecomicindo.com

Pada wacana di atas terdapat premis mayor "Hari Senin Serem" dan premis minor "Ujian juga serem". Dari kedua premis tersebut akhirnya ditarik simpulan bahwa ujian di hari Senin akan kelar (selesai) hidupnya (karena seramnya berlipat).

Meme dengan penggunaan singkatan terdapat pada contoh berikut ini.

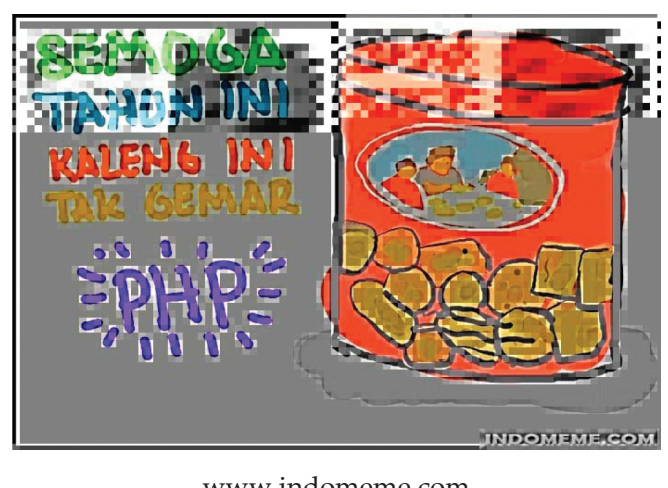

Dalam meme di atas terdapat wacana "Semoga tahun ini kaleng ini tak gemar PHP" dengan gambar meme sebuah kaleng biskuit khong Guan. Implikatur dalam meme ini yaitu menyarankan supaya ketika lebaran tiba kaleng ini benar-benar biskuit khong guan bukan isi yang lain misal rengginang, selondok, dan sebagainya. Ini dikarenakan biasanya ibu-ibu senang menyimpan kaleng bekas biskuit ini dan mengisinya lagi dengan makanan lainnya. Kemudian ketika lebaran tiba ketika anak muda atau siapa pun membuka kaleng ini dengan harapan dapat menikmati lezatnya biskuit ternyata di dalamnya berisi makanan yang lain. PHP dalam hal ini kependekan dari pemberi harapan palsu. Jadi berharap supaya ibuibu tidak memberi harapan palsu pada mereka. Seperti sudah diketahui bahwa khong guan biskuit yang legendaris dengan gambar ibu dan anak laki-laki dan perempuan di meja makan.

Dalam meme juga digunakan peribahasa untuk mendukung implikatur. Peribahasa adalah ungkapan-ungkapan pendek yang berisikan nasihat atau peringatan dan kebenaran umum (Wijana, 2004: 195). Berikut ini contoh meme dengan peribahasa. 


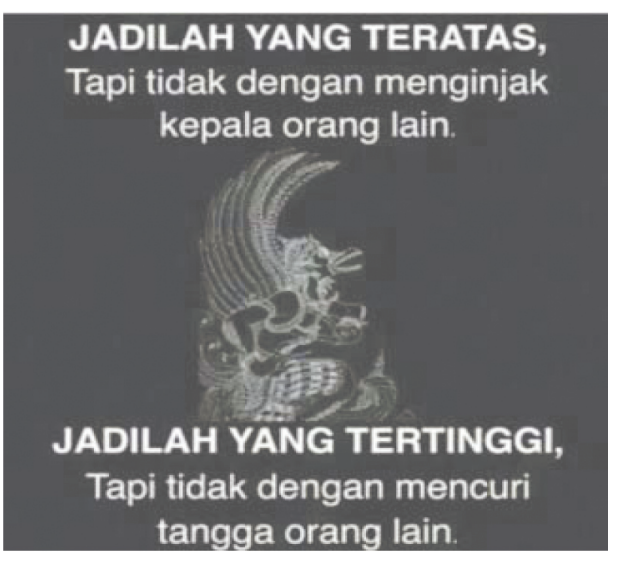

www.memecomicindo.com

Pada wacana meme di atas terdapat peribahasa yang berisi nasihat bahwa untuk menjadi manusia yang unggul kita tidak boleh mengambil jalan yang tidak baik, tidak dengan merugikan dan menindas orang lain. Selain memberi nasihat, sebenarnya meme tersebut juga berisi sindiran atas tingkah laku manusia yang menghalalkan segala cara untuk mendapatkan kesuksesan.

\section{SIMPULAN}

Berdasarkan hasil penelitian dan pembahasan dapat disimpulkan hal-hal berikut ini. Dari sebanyak 70 meme yang berasal dari 4 situs meme di Indonesia ditemukan 4 buah tema dengan berbagai topik di dalamnya. Keempat tema tersebut berturut-turut, yaitu tema sosial, politik, hukum, dan agama. Dari 4 tema tersebut, tema sosial paling banyak ditemukan. Topik-topik dalam tema sosial ini meliputi cinta, sekolah, persahabatan, hubungan dengan orang lain, dan kehidupan sosial lainnya. Topik yang paling banyak muncul, yaitu tentang cinta (walaupun secara frekuensi sama dengan topik kehidupan sosial lainnya, tetapi topik di kehidupan sosial lainnya terdiri dari sub-subtopik lagi). Hal ini dikarenakan baik pengelola situs meme maupun netizen pembuat dan pengirim meme sebagian besar memang anak muda. Selanjutnya, hater presiden, DPR, anggota DPR, merupakan topik dari tema politik. Topik dari tema hukum berkaitan dengan polisi dan aturan berlalu lintas dan yang terakhir topik puasa, sholat, qurban, idhul fitri, dan ibadah kerja termasuk dalam tema agama.

Selanjutnya, dari penelitian meme di media daring yang telah dilakukan ditemukan tiga implikatur, yaitu menyindir, menyarankan, dan gabungan antara menyindir dan menyarankan. Implikatur yang paling banyak yaitu menyindir, disusul menyarankan, dan hanya sebagian kecil implikatur menyindir sekaligus menyarankan.

Yang terakhir, terdapat dua aspek kebahasaan yang mendukung implikatur dan menimbulkan kelucuan dalam meme, yaitu aspek fonologis dan aspek semantis. Aspek fonologis yang ada yaitu pengulangan bunyi atau dalam sastra sering disebut dengan istilah rima/ persajakan. Sementara itu, aspek semantis meliputi pengulangan kata, penggunaan simile, metafora, hiperbola, personifikasi, silogisme, singkatan, dan peribahasa. Aspek semantis berupa pengulangan kata paling banyak digunakan untuk menonjolkan maksud tertentu disusul dengan aspek fonologis yang berupa pengulangan bunyi.

\section{UCAPAN TERIMA KASIH}

Artikel ini disarikan dari hasil penelitian yang dibiayai oleh Dana DIPA FBS UNY tahun 2015. Oleh karena itu, ucapan terima kasih disampaikan kepada Dekan Fakultas Bahasa dan Seni Universitas Negeri Yogyakarta dan BPPF FBS UNY yang telah memberikan kesempatan kepada penulis untuk melakukan penelitian ini. Ucapan terima kasih juga disampaikan kepada semua pihak yang telah memberikan arahan dan masukan dalam penelitian ini.

\section{DAFTAR PUSTAKA}

Allifiansyah, Sandy. "Kaum Muda, Meme, dan Demokrasi Digital di Indone- 
sia". Jurnal Ilmu Komunikasi, Volume 13, Nomor 2 Desember 2016, halaman 151-164. Diunduh dari https:// ojs.uajy.ac.id/index.php/jik/article/ viewFile/676/765, pada tanggal 30 Maret 2017.

Bauckhage, Christian. 2011. "Insight into Internet Memes". Proceedings of the Fifth International AAAI Conference on Weblogs and Social Media. Diunduh dari http://www.aaai.org/ocs/ index.php/ICWSM/ICWSM11/paper/ viewFile/2757/3304

Brown, Gillian dan George Yule. 1996. Analisis Wacana. Edisi terjemahan oleh I Soetikno. Jakarta: gramedia Pustaka Utama.

Danandjaja, James. 1986. Folklor Indonesia: Ilmu Gosip, Dongeng, dan Lain-Lain. Jakarta: Pustaka Grafiti Press.

Departemen Pendidikan Nasional. 2005. Kamus Besar Bahasa Indonesia. Jakarta: Balai Pustaka.

Echols, John dan Hasan Shadily. 1984. Kamus Inggris-Indonesia. Jakarta: Gramedia.

Eriyanto. 2006. Analisis Wacana: Pengantar Analisis Teks Media. Yogyakarta: LkiS Pelangi Aksara.

Mulyana. 2005. Kajian Wacana. Yogyakarta: Tiara Wacana.

Nugraha, Aditya, dkk. 2015. “Fenomena Meme di Media Sosial: Studi Etnografi Virtual Posting Meme pada Pengguna Media Sosial Instagram". Jurnal Sosioteknologi, Volume 14, Nomor 3, Desember 2015, halaman 237-245. Di- unduh dari http://journals.itb.ac.id/index.php/sostek/article/view/1558/1069 pada tanggal 30 Maret 2017.

Nurgiyantoro, Burhan. 2012. Teori Pengkajian Fiksi. Yogyakarta: Gadjah Mada University Press.

Pusanti, Rosa Redia dan Haryanto. "Representasi Kritik dalam Meme Politik (Studi Semiotika Meme Politik dalam Masa Pemilu 2014 pada Jejaring Sosial "Path" sebagai Media Kritik di Era Siber". Diunduh dari http:// www.jurnalkommas.com, tanggal 15 Februari 2017.

Rani, Abdul, dkk. 2004. Analisis Wacana: Sebuah Kajian Bahasa dalam Pemakaian. Malang: Banyumedia Publishing

Sayuti, Suminto A. 2000. Berkenalan dengan Prosa Fiksi. Yogyakarta: Gama Media.

Shifman, Limor. 2013. "Memes in a Digital World: Reconciling with a Conceptual Troublemaker". Journal of ComputerMediated Communication, Volume 18, Issue 3, Version of Record Online 26 Maret 2013. Diunduh dari http:// onlinelibrary.wiley.com/doi/10.1111/ jcc4.12013/pdf

Wijana, I Dewa Putu. 2004. Kartun: Studi tentang Permainan Bahasa. Yogyakarta: Ombak.

Yule, George. 2006. Pragmatics. England: Oxford University Press (terjemahan dalam bahasa Indonesia oleh Indah Fajar Wahyuni, dengan judul Pragmatik). Yogyakarta: Pustaka Pelajar. 